\title{
PERSPEKTIF GENDER PENYADAP GETAH PINUS (STUDI DARI ASPEK PERAN PEKERJAAN DAN PENDAPATAN PADA KELUARGA PENYADAP GETAH PINUS DI DESA JAMBEWANGI KPH BANYUWANGI BARAT)
}

\author{
Leni Wulansari ${ }^{1}$, Sukidin ${ }^{1}$, Pudjo Suharso ${ }^{1}$ \\ ${ }^{1}$ Program Studi Pendidikan Ekonomi, Fakultas Keguruan dan Ilmu Pendidikan Universitas Jember \\ E-mail : Lenywulan@yahoo.com
}

\begin{abstract}
Abstrak
Era globalisasi ditandai dengan kesetaraan gender, dimana kedudukan dan peranan laki-laki maupun perempuan setara serta tidak ada yang paling dominan. Pekerjaan penyadap pinus merupakan pekerjaan yang mayoritas dilakukan oleh laki-laki namun karena berbagai faktor perempuan ikut dilibatkan dalam bekerja menjadi penyadap. Perempuan yang bekerja sebagai penyadap pinus di Desa Jambewangi mengalami penyengsaraan dan memikul beban yang berat, selain harus bertanggung jawab atas pekerjaan rumah tangga perempuan juga ikut bertanggung jawab atas pekerjaan sebagai penyadap getah pinus. Tujuan yang diharapkan dalam penelitian ini adalah mampu (1) Mendeskripsikan perkembangan peran perempuan dalam bekerja sebagai penyadap di Desa Jambewangi. (2) Mendeskripsikan peran perempuan dalam keluarga (3) Mendeskripsikan kontribusinya terhadap pendapatan penyadap getah pinus. Teknik penentuan informan dalam penelitian ini menggunakan teknik snowball. Lokasi penelitian yaitu di Desa Jambewangi yang berada di wilayah Kesatuan Pemangkuan Hutan Banyuwangi Barat. Metode pengumpulan data yang digunakan terdiri dari metode: wawancara mendalam, observasi dan dokumen. Analisis data yang digunakan yaitu mereduksi data, menyajikan data dan penarikan kesimpulan. Hasil penelitian menunjukkan bahwa (1) peran perempuan dalam penyadapan pinus mengalami perkembangan, awalnya perempuan hanya membantu pada saat pemulungan getah saja, setelah itu perempuan belajar melakukan pembaruan luka dan penyemprotan CAS. (2) Curahan waktu kerja masing-masing penyadap hampir sama, namun terdapat perempuan yang memiliki peran lebih banyak dibandingkan laki-laki yaitu sebesar $6,71 \mathrm{Jam} /$ Hari sedangkan laki-laki hanya 1,86 Jam/Hari. (3) Pengambilan keputusan dalam kegiatan domestik di dominasi oleh perempuan, sedangkan pengambilan keputusan dalam kegiatan publik dilakukan bersama-sama antara perempuan dan laki-laki. (4) terdapat perempuan yang memiliki kontribusi lebih besar dari pada laki-laki yaitu sebesar 75\%.
\end{abstract}

Kata Kunci: Peran Pekerjaan, Tata Kelola Keluarga, Pendapatan, Penyadap Getah Pinus.

\section{PENDAHULUAN}

Era globalisasi yang ditandai dengan kesetaraan gender, dimana kedudukan dan peranan laki-laki maupun perempuan setara serta tidak ada yang paling dominan. Wanita sebagai ibu dalam keluarga mempunyai kedudukan yang sama nilainya, perbedaan yang ada dalam keluarga hanyalah mengenai kodrat yang khusus yang dimiliki wanita, misalnya sistem reproduksi dan ciri fisik (Aswiati,2016:3). Kesetaraan ini dukung dengan Undang-Undang No. 40 tahun 2008 yang menjelaskan bahwa semua warga negara berhak mendapat perlakuan yang sama karena semuanya memiliki kedudukan yang sama dihadapan Tuhan yang maha esa.

Persamaan kedudukan memberikan peluang untuk perempuan bisa bekerja di luar rumah baik di sektor formal maupun di sektor infomal. Perempuan dengan tingkat pendidikan dan keterampilan yang rendah banyak masuk ke lapangan kerja terutama pada sektor informal, motivasi perempuan miskin bekerja adalah untuk menambah pendapatan keluarga (Haryanto,2008:217). Perempuan yang bekerja pada sektor informal mampu mengerjakan pekerjaan laki-laki yang mengandalkan otot dan fisik yang kuat, misalnya perempuan yang menjadi kuli panggul. Perempuan yang melakukan pekerjaan laki-laki juga terjadi di Desa Jambewangi, dimana perempuan melakukan pekerjaan yang mengandal otot dan fisik.

Desa Jambewangi berada di BKPH Kalisetail yang terdapat di wilayah KPH Banyuwangi Barat. Di Desa Jambewangi banyak pohon pinus dibawah naungan Perum Perhutani Unit II Jawa Timur, sebagai wujud kepedulian Perhutani terhadap masyarakat sekitar hutan dengan mengikutsertakan masyarakat sekitar untuk menjadi penyadap getah pinus sama halnya yang terjadi di Desa Jambewangi. Perhutani memberikan lahan kepada penyadap untuk di sadap, sebagai gantinya Perhutani membeli hasil sadapan penyadap dengan harga yang telah ditentukan oleh Perum Perhutani.

Berdasarkan hasil observasi awal masyarakat sekitar hutan tergolong sebagai keluarga miskin, termasuk masyarakat Desa Jambewangi yang mayoritas penduduknya sebagai penyadap getah pinus. Hal ini dapat di lihat dari pola hidup dan ketersediaan pangan yang memperihatinkan. Kondisi ini disebabkan karena pendapatan 
DOI:

yang diterima oleh penyadap getah pinus belum dapat memenuhi kebutuhan sehari-hari seperti untuk makan, untuk memberi uang saku anak, untuk nyumbang kepada tetangga yang memiliki hajatan dan lain sebagainya.

Perempuan miskin mengalami penyengsaraan, dimana perempuan harus bertanggung jawab atas pekerjaan rumah tangga dan juga kebutuhan ekonomi rumah tangganya sehingga perempuan juga harus bekerja diluar rumah (Hidayati,2015:112). Penyadapan getah pinus di Desa Jambewangi awalnya hanya dilakukan oleh laki-laki saja, karena kemiskinan perempuan juga dilibatkan dalam pekerjaan sebagai penyadapan getah pinus. Perempuan yang awalnya hanya memiliki peran domestik untuk mengurus semua pekerjaan rumah, karena kemiskinan menyebabkan perempuan bekerja membantu laki-laki menjadi penyadap getah pinus untuk meningkatkan pendapatan keluarga. Partisipasi perempuan dalam bekerja sebagai penyadap getah pinus dapat dilihat dari tabel di bawah ini.

Tabel 1. Total Penyadap Getah Pinus di Desa Jambewangi

\begin{tabular}{llcc}
\hline No. & TPG (tempat penampungan \\
getah) & $\begin{array}{c}\text { Total penyadap laki- } \\
\text { laki }\end{array}$ & Total penyadap perempuan \\
\hline 1. & Bambusa & 54 penyadap & 2 penyadap \\
2. & Watu gedhek & 34 penyadap & 5 penyadap \\
3. & Seling & 25 penyadap & 7 penyadap \\
4. & Gunung payung & 54 penyadap & 5 penyadap \\
\hline & Total & $\mathbf{1 6 7}$ Penyadap & 19 Penyadap \\
\hline
\end{tabular}

Sumber : Bagian Kesatuan Pemangkuan Hutan Kalisetail Tahun 2018.

Dilihat dari tabel diatas jumlah perempuan yang bekerja sebagai penyadap pinus secara penuh yaitu sejumlah 19 penyadap, sedangkan laki-laki sebanyak 167 penyadap. Partisipasi perempuan yang menjadi penyadap getah pinus untuk membantu laki-laki bekerja cukup banyak, namun produktivitas penyadap getah pinus berbeda-beda tergantung dari keuletan penyadap getah pinus baik laki-laki maupun perempuan. Penyadap yang motivasi bekerja tinggi, luas lahan yang luas, dan pada saat bekerja dibantu oleh perempuan maka produktivitasnya juga banyak.

Tabel di atas menunjukkan bahwa peran perempuan bukan hanya sebagai ibu rumah tangga, tetapi perempuan juga bisa bekerja sebagai penyadap getah pinus. Perempuan yang selalu dianggap hanya pantas mengerjakan pekerjaan rumah, namun perempuan bisa mengerjakan pekerjaan laki-laki khususnya sebagai penyadap getah pinus. Peran perempuan dalam penyadapan getah pinus di Desa Jambewangi mulai dari pembaruan luka pada pohon pinus, penyemprotan cairan asam stimulan agar getah yang dihasilkan banyak, hingga pemanenan getah pinus. Pada mulanya perempuan yang membantu suami dalam penyadapan hanya proses pemanenan getah pinus saja, namun karena dirasa tenaganya kurang dioptimalkan karena setelah perempuan mengerjakan pekerjaan domestik perempuan menganggur dan pendapatan yang diterima jika lakilaki saja yang bekerja belum cukup maka peran perempuan dimaksimalkan.

Peran perempuan yang awalnya hanya pemanenan getah saja, namun perempuan mulai melakukan proses penyadapan yang dianggap ringan seperti penyemprotan cairan asam stimulan. Peran perempuan yang hanya melakukan penyemprotan saja mengalami perkembangan dimana perempuan mampu melakukan pembaruan luka pada pohon pinus hingga menaikkan talang dan tempurung. Saat ini perempuan mampu mengerjakan semua tahapan penyadapan tanpa terkecuali.

Perempuan yang dilibatkan dalam penyadapan getah pinus untuk mempercepat pekerjaan dan untuk menambah produktivitas, karena pekerjaan yang dilakukan oleh dua orang dirasa lebih efisien dan produktivitasnya lebih banyak jika dibandingkan laki-laki bekerja sendiri. Pendapatan laki-laki jika bekerja sendiri dilihat dari produktivitas getah yang dihasilkan hanya bisa menghasilkan 3 drum, namun jika perempuan dilibatkan dalam pekerjaan produktivitas getah yang dihasilkan juga meningkat yaitu bisa lima drum.

Peran laki-laki dan perempuan yang bekerja sebagai penyadap getah pinus tentunya berbeda karena fisik laki-laki lebih kuat dibandingkan dengan perempuan. Jumlah pohon pinus yang disadap lebih banyak laki-laki dikarenakan laki-laki lebih dahulu bekerja sehingga sudah mahir dibandingkan dengan perempuan yang masih pemula dalam penyadapan.

Penelitian yang dilakukan oleh Prastiwi (2015:3) menunjukkan bahwa dilihat dari curahan waktu kerja, peran laki-laki lebih besar dari pada perempuan dalam kegiatan penyadapan pinus, laki-laki sebesar 39,61 jam/minggu dan perempuan sebesar 9,07 jam/minggu. Dalam penelitian tersebut peran perempuan hanya melakukan kegiatan CAS dan pemungutan getah pinus saja. Hasil penelitian ini hampir sama dengan yang terjadi di Desa Jambewangi, berdasarkan hasil observasi awal yang telah di lakukan peran perempuan dalam pekerjaan menjadi penyadap getah pinus hingga pembaruan luka (koakan), penyemprotan CAS (cairan asam stimulan), menaikkan talang dan tempurung hingga naik turun dan membawa tangga dari satu pohon ke pohon lain, hingga pemanenan getah pinus. 
DOI:

Peningkatan peran perempuan menimbulkan berbagai pertanyaan, karena perempuan yang bekerja menjadi penyadapan getah pinus mengalami eksploitasi. Perempuan bekerja berapapun produksinya tidak diakui oleh pihak perhutani dan dianggap sebagai hasil produksi laki-laki, perempuan juga di eksploitasi tenaganya selain bekerja menjadi penyadap perempuan juga bertanggung jawab terhadap pekerjaan domestik. Perempuan juga tidak menerima pendapatan karena pendapatannya yang menerima laki-laki, namun perempuan tetap bekerja membantu laki-laki dalam penyadapan padahal perempuan bisa bekerja di sektor lain dan mendapatkan upah sendiri.

Berdasarkan pemaparan di atas, maka peneliti bermaksud mengadakan penelitian yang bertujuan untuk mengetahui perekembangan peran perempuan yang bekerja sebagai penyadap pinus, untuk mengetahui peran perempuan dalam keluarga dan untuk mengetahui kontribusinya terhadap pendapatan.

\section{METODE PENELITIAN}

Penelitian ini merupakan penelitian deskriptif dengan pendekatan kualitatif untuk mendeskripsikan bagaimana perkembangan peran perempuan dalam bekerja sebagai penyadap getah pinus di Desa Jambewangi, untuk mendeskripsikan peran perempuan dalam keluarga dan untuk mendeskripsikan kontribusinya terhadap pendapatan. Lokasi penelitian yaitu di Desa Jambewangi yang berada di wilayah Kesatuan Pemangkuan Hutan Banyuwangi Barat. Penentuan subjek penelitian menggunakan metode snowball yaitu penyadap getah pinus wanita yang berjumlah 6 (enam) informan yaitu SG, SH, SA, MS, SM dan MS. Metode pengumpulan data menggunakan metode: wawancara mendalam, observasi partisipasi dan dokumentasi. Analisis data menggunakan: reduksi data, penyajian data dan penarikan kesimpulan atau verifikasi data.

\section{HASIL DAN PEMBAHASAN Hasil Penelitian Peran Pekerjaan}

Pada saat awal bekerja menjadi penyadap informan pokok hanya membantu saat pemulungan atau pemanenan getah pinus saja, dalam satu periode kerja (kurang lebih 15 hari) perempuan hanya bekerja selama tiga hari saja pada saat pemanenan getah pinus. Ketika pemanenan getah sudah selesai informan kembali ke pekerjaannya semula yaitu ibu rumah tangga, buruh tani dan mencari sayuran. Pada mulanya laki-laki mengerjakan setiap tahapan penyadapan sendiri kecuali pemulungan getah selalu dilakukan bersama dengan istrinya, namun karena perempuan dianggap mampu untuk melakukan tahapan lainya.

Pada awal bekerja informan diajari pembaruan luka setelah mahir, penyemprotan cairan asam dan pemulungan getah. Informan pokok diajari setiap tahapan penyadapan oleh suaminya, namun terdapat fenomena yang menarik yang terjadi di Desa Jambewangi dimana terdapat satu informan pokok yang mengajari suaminya bekerja menjadi penyadap getah pinus, informan belajar menjadi penyadap diajari oleh kedua orang tuanya. Dalam mempelajari setiap tahapan informan membutuhkan waktu selama tiga hingga lima bulan lamanya hingga informan mahir.

Peran pekerjaan dalam penyadapan getah pinus terdiri dari pembaruan luka pada pohon pinus, penyemprotan cairan asam stimulantia, pemanenan dan pengangkutan getah pinus ke TPG (tempat penampungan getah). Peran dalam pekerjaan penyadap dilakukan bersama-sama antara suami dan istri, setiap tahapan dikerjakan bersama dengan cara blok sadap dibagi menjadi dua bagian serta masing-masing mengerjakan satu bagian dan cara kedua adalah istri bekerja beriringan atau berdampingan dengan suami karena beralasan takut bekerja sendiri di hutan.

Tahapan pertama yang dikerjakan adalah pembaruan luka pada pohon pinus. Pembaruan luka pada pohon pinus dilakukan kurang lebih selama 3-5 hari tergantung dengan kondisi fisik penyadap, cuaca dan luas blok sadap, untuk koakan yang tinggi terdapat informan yang tetap mengerjakannya dan terdapat informan yang menyerahkan pohon yang memiliki koakan tinggi kepada suaminya. Dalam satu hari bekerja jumlah pohon yang diperbarui koakannya antara informan satu dengan yang lainnya berbeda, dalam satu hari bekerja informan pokok dalam memperbarui koakan mencapai 50-100 pohon sedangkan informan tambahan bisa mencapai 100200 pohon setiap harinya.

Setelah proses pembaruan luka selesai, tahap selanjutnya adalah penyemprotan cairan asam stimulantia. Cairan ini berasal dari senyama kimia yang larut di dalam air yang bersifat asam. Penyemprotan CAS ini dilakukan secara bersama-sama. Penyemprotan CAS ini dilakukan selama kurang lebih 3 hari. Penyemprotan CAS ini dilakukan selama 2 kali setiap periodenya dan dilakukan setelah pembaruan luka.

Pemulungan getah pinus dilakukan bersama-sama baik informan pokok dan suaminya. Informan pokok hanya dapat membawa separuh timba yang sudah berisi getah pinus lalu memindahkan ke timba lain, setelah penuh suami betugas untuk memikul dan memindahkan ke drum besar yang telah disediakan pihak Perhutani. 
DOI:

Curahan waktu kerja merupakan waktu kerja yang dibutuhkan oleh penyadap untuk bekerja setiap waktunya, rata-rata curahan waktu kerja informan dalam bekerja menadi penyadap terdapat pada Tabel 2 yaitu sebagai berikut :

Tabel 2. Curahan Waktu Kerja Perempuan dan Laki-laki dalam Menyadap Getah Pinus

\begin{tabular}{lcccc}
\hline \multirow{2}{*}{ No. } & \multicolumn{2}{c}{ Nama Keluarga } & \multicolumn{2}{c}{ Curahan Waktu Kerja (Jam/Hari) } \\
\cline { 2 - 5 } & Laki-laki/Suami & Perempuan/Istri & Laki-laki/Suami & Perempuan/Istri \\
\hline 1. & Suprapto & Sugiati & 6.29 & 6.14 \\
2. & Ghuno & Saminah & 7.86 & 7.71 \\
3. & Rohman & Siti Aminah & 6.29 & 6.14 \\
4. & Sujani & Mar'atus Solikah & 6.57 & 6.14 \\
5. & Seniman & Samini & 1.86 & 6.71 \\
6. & Napik & Misti & 7.43 & 7.42 \\
\hline
\end{tabular}

Sumber: Data Primer (diolah), 2018

Berdasarkan Tabel 2 menunjukkan bahwa rata-rata curahan waktu kerja antara laki-laki dan perempuan lebih banyak laki-laki, selisih waktu kerja ini disebabkan karena laki-laki memiliki peran lainnya yaitu harus mengangkut getah dari blok sadap menuju ke tempat penampungan getah. Namun, terdapat satu informan yang memiliki curahan waktu lebih banyak perempuan dibandingkan dengan laki-laki yaitu 6,71 jam/hari sedangkan laki-laki hanya $1,86 \mathrm{jam} / \mathrm{hari}$. Berdasarkan hasil penelitian hal ini disebabkan karena laki-laki sering mengerjakan pekerjaan lain seperti merawat dan mencabut ketela pohon sehingga perempuan harus bekerja sendiri. Informan pokok berangkat bekerja setelah menyelesaikan pekerjaan rumah dan setelah anak pergi ke sekolah, informan berangkat bekerja pukul 07.00 WIB dan pulang bekerja antara pukul 16.00 - 17.00 WIB. Informan pokok bekerja menjadi penyadap setiap hari dan libur bekerja ketika ada tetangga maupun saudara yang meninggal, rewang atau membantu orang yang memiliki hajatan, sayan (membantu orang yang membangun rumah), hajatan dan sakit. Namun ketika informan tambahan sakit informan pokok ada yang tetap bekerja dan ada yang tidak bekerja.

\section{Tata Kelola Keluarga dan Pendapatan Penyadap Getah Pinus}

Tata kelola keluarga penyadap meliputi pengambilan keputusan dalam keluarga, pengelolaan keuangan dan pendidikan anak. Berdasarkan hasil penelitian terhadap enam informan, pengambilan keputusan yang dilakukan bersama-sama adalah dalam pendidikan anak, pembelian barang mewah dan tempat berobat. Pengambilan keputusan dalam kegiatan kemasyarakatan enam informan menjawab bahwa keputusan sendiri. Pengambilan keputusan yang di dominasi oleh informan pokok adalah makanan yang akan dikonsumsi, dan pembelian alat rumah tangga.

Hasil penelitian menunjukkan bahwa dalam pengelolaan keuangan di dominasi oleh perempuan, informan pokok berperan penting dalam pembelanjaan uang untuk kebutuhan sehari-hari. perencanaan keuangan dilakukan bersama-sama antara suami dan istri. Berdasarkan hasil penelitian terhadap enam informan, ketika anak masih kecil keenam informan menjawab bahwa yang menemani anak dan merawat anak. Hasil penelitian tentang yang menemani anak belajar dan mengajari PR anak, informan menjawab jika masih kecil didampingi ibu atau kakaknya dan ketika anak sudah remaja mereka belajar sendiri.

Penyadap getah pinus memperoleh upah setiap periodenya, satu periode terdiri dari lima belas hari dan dalam satu bulan terdapat dua periode pembayaran. Pendapatan penyadap di pengaruhi oleh berbagai faktor yaitu luas blok sadap, musim, motivasi kerja penyadap sendiri, harga getah dan masih banyak lagi Suami dahulu bekerja sendiri, sebelum dibantu dengan istri hasil produksi dan pendapatan penyadap akan disajikan dalam Tabel 3 yaitu sebagai berikut :

Tabel 3. Jumlah Produksi dan Pendapatan Penyadap Sebelum Dibantu Istri

\begin{tabular}{lccc}
\hline No. & Nama Penyadap & $\begin{array}{c}\text { Jumlah Getah yang } \\
\text { Dihasilkan (Drum) }\end{array}$ & $\begin{array}{c}\text { Total pendapatan } \\
\text { (setiap peiode) }\end{array}$ \\
\hline 1. & Suprapto & 3 & Rp. $1.200 .000,00$ \\
2. & Guno & 2 & Rp. $800.000,00$ \\
3. & Fatkur Rohman & 2 & Rp. $800.000,00$ \\
4. & Sujani & 1 & Rp. $400.000,00$ \\
$\mathbf{5 .}$ & Seniman & 1 & Rp. $400.000,00$ \\
6. & Napik & 2 & Rp. $800.000,00$ \\
\hline
\end{tabular}

Sumber : Data Primer (diolah), 2018

Tabel diatas menunjukkan produksi dan pendapatan penyadap, karena pendapatan tidak mencukupi istri 
DOI:

dilibatkan dalam bekerja menjadi penyadap berikut adalah jumlah produksi dan pendapatan penyadap setelah istri ikut bekerja sebagai berikut :

Tabel 4. Jumlah Produksi dan Pendapatan Penyadap setelah Istri Ikut Bekerja

\begin{tabular}{lccl}
\hline No. & Nama Keluarga Penyadap & Jumlah Produksi (Drum) & Pendapatan \\
\hline 1. & Suprapto dan Sugiati & 5 & Rp. 2.000.000,- \\
2. & Ghuno dan Saminah & 4 & Rp. 1.600.000,- \\
3. & Rohman dan Siti Aminah & 3 & Rp. 1.200.000,- \\
4. & Sujani dan M. Likah & 2 & Rp. 800.000,- \\
5. & Seniman dan Smaini & 2 & Rp. 800.000,- \\
6. & Napik dan Misti & 3 & Rp. 1.200.000,- \\
\hline
\end{tabular}

Sumber: Data Primer (diolah), 2018

Berdasarkan Tabel diatas menunjukkan adanya peningkatan pendapatan sebelum dibantu oleh istri dan setelah dibantu oleh istri, adanya peran perempuan dalam pekerjaan menunjukkan bahwa perempuan berkontribusi dalam pendapatan. Kontribusi pendapatan perempuan dalam meningkatkan pendapatan keluarga dapat dilihat pada tabel di bawah ini :

Tabel 5. Kontribusi Pendapatan Istri Penyadap Terhadap Total Pendapatan Keluarga

\begin{tabular}{lcc}
\hline No. & Nama Penyadap & $\begin{array}{c}\text { Kontribusi } \\
\text { (dalam persen) }\end{array}$ \\
\hline $\mathbf{1 .}$ & Sugiati & $40 \%$ \\
$\mathbf{2 .}$ & Saminah & $50 \%$ \\
$\mathbf{3 .}$ & Siti Aminah & $33,3 \%$ \\
$\mathbf{4 .}$ & Mar'atus Sholikah & $50 \%$ \\
$\mathbf{5 .}$ & Samini & $75 \%$ \\
$\mathbf{6 .}$ & Misti & $50 \%$ \\
\hline
\end{tabular}

Sumber : Data Primer (diolah), 2018

Berdasarkan tabel 5 menunjukkan kontribusi pendapatan istri penyadap terhadap pendapatan keluarga penyadap getah pinus. Tabel diatas menunjukkan besarnya kontribusi masing-masing istri penyadap berbeda, namun terapat fenomena yang menarik dimana kontribusi istri lebih besar dibandingkan suaminya, istri memiliki kontribusi pendapatan yang besarnya 75\% sedangkan suami memiliki kontribusi sebanyak $25 \%$. Suami memiliki kontribusi yang lebih kecil karena sering bekerja menjadi pencabut ketela sehingga sering libur bekerja.

\section{Pembahasan}

Motivasi perempuan bekerja menjadi penyadap getah pinus adalah karena faktor ekonomi, perempuan harus bekerja untuk menyokong perekonomian keluarga dan untuk menambah tingkat kehidupan keluarga, penelitian ini sesuai dengan pendapat William J. Goode (2007:5) yang menyebutkan bahwa wanita bekerja terutama terdorong oleh kemiskinan, labih banyak orang bekerja untuk menambah tingkat kehidupan keluarga atau karena mereka ingin bekerja.

Peran perempuan dalam penyadapan awalnya membantu pemanenan getah pinus saja dirasa kurang optimal, perempuan dirasa mampu untuk melakukan semua tahapan penyadapan getah pinus seperti pembaruan luka, penyemprotan CAS dan pemulungan getah. Tindakan perempuan ini dibenarkan oleh teori utilitarianisme karena memaksimalkan perannya dalam penyadapan getah pinus (Niam, 2008:92). Peran perempuan yang dimaksimalkan akan mempercepat waktu pengerjaan penyadapan getah pinus dan dapat meningkatkan pendapatan.

Peran perempuan dan laki-laki dapat dilihat dari curahan waktu kerja masing-masing penyadap, curahan waktu kerja merupakan waktu kerja yang dibutuhkan oleh penyadap untuk bekerja setiap waktunya, rata-rata curahan waktu kerja informan dalam bekerja menadi penyadap terdapat pada Tabel 6 yaitu sebagai berikut :

Tabel 6. Rata-Rata Curahan Waktu Kerja Dalam Menyadap Getah Pinus

\begin{tabular}{lcccc}
\multirow{2}{*}{ No. } & \multicolumn{2}{c}{ Nama Keluarga } & \multicolumn{2}{c}{ Curahan Waktu Kerja (Jam/Hari) } \\
\cline { 2 - 5 } & Laki-laki/Suami & Perempuan/Istri & Laki-laki/Suami & Perempuan/Istri \\
\hline 1. & Suprapto & Sugiati & 6.29 & 6.14 \\
2. & Ghuno & Saminah & 7.86 & 7.71 \\
3. & Rohman & Siti Aminah & 6.29 & 6.14 \\
\hline
\end{tabular}


DOI:

\begin{tabular}{lccll}
\hline 4. & Sujani & Mar'atus Solikah & 6.57 & 6.14 \\
5. & Seniman & Samini & 1.86 & 6.71 \\
6. & Napik & Misti & 7.43 & 7.42 \\
\hline
\end{tabular}

Sumber : Data Primer (diolah), 2018

Berdasarkan Tabel 6 menunjukkan fenomena yang menarik dimana perempuan memiliki curahan waktu kerja yang lebih banyak dibandingkan dengan laki-laki. Pada hakekatnya perempuan dipandang feminis yang memiliki sifat lemah lembut, cantik, emosional atau keibuan dan memiliki fisik yang lemah dibandingkan dengan laki-laki yang dianggap kuat, rasional, jantan dan perkasa (Fakih, 2013:8), namun berdasarkan hasil penelitian yang telah dilakukan perempuan mampu mengerjakan pekerjaan maskulin. Perempuan mampu melakukan setiap tahapan dalam penyadapan. Perempuan juga terlihat lebih maskulin dibandingkan laki-laki, berdasarkan hasil penelitian beberapa perempuan memiliki fisik lebih kuat dibandingkan dengan laki-laki. Perempuan terbukti lebih cepat dan cekatan dalam pekerjaan, misalnya dalam memperbarui luka pada pohon pinus perempuan lebih cepat dibandingkan dengan laki-laki.

Tata kelola keluarga terdiri dari pengambilan keputusan dalam keluarga, pengelolaan keuangan serta pendidikan dan pengawasan anak. Deacon dan Firebough mengemukakan bahwa pengambilan keputusan merupakan proses yang mendasari semua fungsi manajemen sumberdaya keluarga (Rani,dkk : 2013:47). Pengambilan keputusan dalam keluarga terdiri dari pengambilan keputusan dalam domestik dan publik. Dalam aspek domestik pengambilan keputusan yang diambil oleh perempuan secara dominan yaitu dalam pengambilan keputusan dibidang pangan, hampir seluruh informan pada keluarga penyadap didominasi oleh perempuan. Pengambilan keputusan dalam hal mengatur menu makanan dan cara pengelolaan makanan dilakukan perempuan saja tanpa melibatkan laki-laki. Hasil penelitian ini sejalan dengan penelitian Rani,dkk (2013:37) bahwa pengambilan keputusan dalam pengeluaran pangan dan urusan makanan atau pangan didominasi oleh istri. Sedangkan dalam aspek publik menyebar antara laki-laki dan perempuan.

Pengambilan keputusan dalam pendidikan anak dilakukan bersama-sama antara suami dan istri, dalam menentukan anak sekolah atau tidak, memilih tempat pendidikan dan mengatur jenjang pendidikan anak adalah keputusan bersama. Hasil penelitian ini sejalan dengan hasil penelitian Prastiwi (2015:6) bahwa pengambilan keputusan dalam penentuan pendidikan dilakukan secara bersama-sama.

Perencanaan keuangan dalam keluarga penyadap dilakukan bersama-sama antara suami dan istri, temuan ini sejalan dengan penelitian Anita (2015:24) bahwa perencanaan keuangan keluarga dilakukan secara bersama antara suami dan istri bahkan dengan anak - anak apabila berkaitan dengan seluruh anggota keluarga. Dalam perencanaan keuangan perempuan membuat perencanaan sesuai dengan kebutuhan dan dipilah menjadi kebutuhan pokok dan untuk kepentingan lainnya dan pengelolaan keuangan hampir seluruh informan didominasi istri.

Pendapatan merupakan seluruh penerimaan baik yang berupa uang maupun barang baik dari pihak luar maupun dari hasil sendiri dengan jalan yang dinilai atas jumlah harga yang berlaku saat itu dalam bentuk uang (Sumardi, 1982:20). Pendapatan penyadap sebelum dibantu dengan perempuan dan setelah dibantu nampak sekali perbedaannya, ketika perempuan bekerja membantu dalam penyadapan pendapatan meningkat namun ketika bekerja sendiri pendapatan yang diperoleh kecil. Perempuan dalam keluarga penyadap memiliki kontribusi terhadap pendapatan total yang diterima dari penyadap getah pinus, berikut adalah tabel kontribusi pendapatan istri penyadap terhadap total pendapatan keluarga :

Tabel 7. Kontribusi Pendapatan Istri Penyadap Terhadap Total Pendapatan Keluarga

\begin{tabular}{ccc}
\hline No. & Nama Penyadap & $\begin{array}{c}\text { Kontribusi } \\
\text { (dalam persen) }\end{array}$ \\
\hline $\mathbf{1 .}$ & Sugiati & $40 \%$ \\
$\mathbf{2 .}$ & Saminah & $50 \%$ \\
$\mathbf{3 .}$ & Siti Aminah & $33,3 \%$ \\
$\mathbf{4 .}$ & Mar'atus Sholikah & $50 \%$ \\
$\mathbf{5 .}$ & Samini & $75 \%$ \\
6. & Misti & $50 \%$ \\
\hline
\end{tabular}

Sumber : Data Primer (Diolah),2018

Berdasarkan tabel 7 menunjukkan bahwa kontribusi perempuan terhadap pendapatan terlihat lebih besar dibandingkan dengan laki-laki yaitu sebesar 75\%. Perempuan yang selalu di pandang feminis menunjukkan bahwa perempuan mampu bekerja sendiri menjadi penyadap tanpa bantuan laki-laki, perempuan menjadi lebih mandiri dan tidak mengandalkan suami dalam mencari nafkah.

Peningkatan pendapatan penyadap tidak berarti kesejahteraan penyadap juga meningkat. Kesejahteraan merupakan terpenuhinya seluruh kebutuhan baik barang maupun jasa dalam memenuhi kebutuhan keluarga. (Rosni, 2017:57). Hasil penelitian menunjukkan bahwa pendapatan penyadap tetap masih belum bisa memenuhi 
DOI:

semua kebutuhan, kebutuhan yang terpenuhi umumnya adalah kebutuhan primer. Pendapatan yang diterima penyadap tidak bisa menutup semua kebutuhan, hal ini disebabkan karena harga kebutuhan pokok yang semakin tinggi.

\section{PENUTUP}

Berdasarkan hasil analisis penelitian maka dapat ditarik suatu kesimpulan bahwa perspektif gender dalam peran domestik di dominasi oleh perempuan, sedangkan perspektif gender dalam peran publik menyebar antara laki-laki dan perempuan. Konstruksi masyarakat di Desa Jambewangi tentang peran laki-laki dan perempuan sudah tidak terlalu nampak, terlihat dari perempuan yang memiliki peran transisi yaitu bekerja untuk meningkatkan kehidupan keluarganya. Curahan waktu kerja masing-masing penyadap hampir sama yaitu 6 jam/hari, namun terdapat satu informan yang memiliki curahan waktu kerja yang lebih banyak. Hal ini membuktikan bahwa perempuan mampu melakukan pekerjaan maskulin yang mengandalkan otot.

Melihat berbagai permasalahan yang dihadapi oleh keluarga penyadap di Desa Jambewangi, maka penulis mencoba memberi saran-saran yang diharapkan bisa bermanfaat bagi semua pihak - pihak terkait bahwa sebagai negara yang kaya akan sumber daya alam, pemerintah diharapkan lebih memperhatikan nasip penyadap getah pinus. Pemerintah perlu menambah wawasan mengenai kegiatan diluar menjadi penyadap getah pinus, ketika musim hujan tiba penyadap tidak akan kesulitan karena memiliki pekerjaan sampingan.

Pihak Perhutani perlu memperhatikan kesehatan penyadap, saat menyemprotkan cairan asam penyadap tidak menggunakan pelindung padahal penyadap langsung terkena dan menghirup cairan asam sulfat. Perlu dibentuk lembaga pemberdayaan perempuan yang menjadi bagian dari pemerintahan daerah dan mendapatkan anggaran khusus. Sehingga program-program yang bertujuan untuk meningkatkan skill perempuan bisa terlaksana dan lebih tepat sasaran.

Penyadap perlu melakukan terobosan lain untuk meningkatkan pendapatan. Di bawah tegakan pinus umumnya tidak ditanami, untuk itu penyadap perlu menanami lahan di bawah tegakan pinus untuk meningkatkan pendapatan. Tanaman yang perlu di tanam adalah jenis umbi - umbian, cabai, dan lain sebagainya. Lahan yang luas bisa di manfaatkan untuk bercocok tanam dengan demikian pendapatan penyadap bisa meningkat.

\section{DAFTAR PUSTAKA}

Anita, R. 2015. Harmoni dalam Keluarga Perempuan Karir: Upaya Mewujudkan Kesetaraan dan Keadilan Gender dalam Keluarga. Palastren. 8 (1).

Aswiyati, Indah. 2016. Peran Wanita Dalam Menunjang Perekonomian Rumah Tangga Keluarga Petani Tradisional Untuk Penanggulangan Kemiskinan Di Desa Kuwil Kecamatan Kalawat. Jurnal Holistik. Vol. IX (17).

Fakih, Mansour. 2013. Analisis gender dan transformasi sosial. Yogyakarta : Pustaka Pelajar.

Goode, William J. 2007. Sosiologi Keluarga. Jakarta: PT Bumi Aksara.

Haryanto, Sugeng. 2008. Peran Aktif Wanita Dalam Meningkatkan Pendapatan Rumah Tangga Miskin (Studi Kasus Pada Wanita Pemecah Batu Di Pucanganak Kecamatan Tugu Trenggalek). Jurnal Ekonomi Pembangunan. Vol.9 (2).

Hidayati, 2015. Nurul. Beban Ganda Perempuan Bekerja (Antara Domestik Dan Publik). Muwazah. Vol 7 (2).

Kusumo,Rani Andriani Budi., Charina, Anne, dan Mukti, Gema Wibawa. 2013. Analisis gender dalam kehidupan keluarga nelayan di kecamatan Pangandaran kabupaten Ciamis. Jurnal social economics of agriculture. Vol. 2 (1)

Niam, Harun. 2008. Utilitarianisme : Sejarah, Konsep dan Peran. Spektrum. Jurnal Ilmu Politik Hubungan Internasional. Vol.5 (2). 
DOI:

Prastiwi. 2015. Analisis gender penyadap pinus di Dusun Sidomulyo, RPH Gunungsari, KPH Banyuwangi Barat, Jawa Timur. Korespondensi.

Rosni. 2017. Analisis Tingkat Kesejahteraan Nelayan Di Desa Dahari Selebar Kecamatan Talawi Kabupaten Batubara. Jurnal Geografi. Vol. 9 (1).

Sumardi. 1982. Sumber Pendapatan, Kebutuhan Pokok dan Perilaku Menyimpang. Jakarta : Rajawali. 